\title{
A conservation assessment of Rousettus madagas- cariensis (G. Grandidier, 1928, Pteropodidae) roosts in eastern Madagascar
}

Radosoa A. Andrianaivoarivelo", "I , Daudet Andriafidison ","l, Christophe Rahaingonirina"l', Sylvèstre Raharimbola"', Andrinajoro A. Rakotoarivelo', Olga R. Ramilijaona", Paul A. Racey ${ }^{I V}$ and Richard K. B. Jenkins, ${ }^{I, V I}$

\begin{abstract}
We visited four cave roosts of the near threatened, and endemic, fruit bat Rousettus madagascariensis over a five year period and found major threats to the bats from hunting and deforestation. The conservation of this species is particularly challenging because it is legally hunted inside its cave roosts. Although provisional protected area status was obtained for two sites with community support, hunting continued. R. madagascariensis roosts were associated with humid forest and the loss of vegetation around caves rendered them unsuitable for the bats at two abandoned sites. A few individual hunters can have a rapid and destructive impact on $R$. madagascariensis roosts and future initiatives in this area should involve working with hunters to develop realistic solutions to reduce hunting. These efforts need to be supported by habitat protection measures.
\end{abstract}

\section{RÉSUMÉ}

L'espèce de chauve-souris frugivore Quasi Menacée Rousettus madagascariensis est endémique à Madagascar. Nous avons étudié quatre gîtes dans des grottes où cette espèce a établi des dortoirs diurnes en procédant à des visites multiples au cours d'une période de cinq ans et avons trouvé que la chasse et la déforestation constituaient les principales menaces pesant sur R. madagascariensis. La conservation de cette espèce est particulièrement difficile dans la mesure où la chasse dans ses dortoirs ou gîtes est permise. Bien que les deux sites abritant l'espèce bénéficient du statut de Nouvelle Aire Protégée avec le soutien de la communauté locale, la chasse ne cesse de $S^{\prime}$ intensifier. Les gîtes de $R$. madagascariensis sont associés à la forêt humide, de sorte que la disparition de la végétation arborée autour de deux de ces gîtes les a rendus impropres à héberger $R$. madagascariensis qui a fini par les abandonner. La disparition de la végétation arborée autour du gîte pourrait être à l'origine d'un changement de microclimat à l'intérieur de la grotte qui constitue le gîte diurne. Les activités de certains

\section{Correspondence:}

Radosoa A. Andrianaivoarivelo

Madagasikara Voakajy, BP 5181, Antananarivo 101

E-mail: aniainodna@yahoo.fr

chasseurs peuvent aussi avoir un impact destructif rapide sur les gîtes de R. madagascariensis et des initiatives à mener conjointement avec les chasseurs sont nécessaires pour élaborer des mesures réalistes afin de réduire la chasse. De tels efforts doivent être étendus et appuyés par des mesures de protection de I'habitat car plusieurs autres gîtes pourraient exister dans les forêts du versant est de Madagascar et subir les mêmes pressions anthropiques. Des recherches récentes ont également montré que I'histoire naturelle de $R$. madagascariensis est étroitement liée à la forêt naturelle, de sorte que la perte de la biodiversité de la forêt naturelle malgache menace les plantes dont se nourrit cette espèce ainsi que l'équilibre de l'ensemble de l'écosystème dont elle dépend.

\section{INTRODUCTION}

Madagascar's three endemic fruit bat species are threatened by hunting, and habitat loss (Mackinnon et al. 2003; Andriafidison $2008 a, b, c)$. Although these bats are classed as game and can be legally hunted between May and August (Durbin 2007, Rakotoarivelo et al. 2011), hunting legislation is rarely enforced (Racey et al. 2010). Bats are hunted for bushmeat in Madagascar whilst feeding on trees at night or roosting in colonies during the day (Jenkins and Racey 2008). Aggregations of roosting bats provide hunters with prime opportunities for capturing or killing large numbers of fruit bats. Hunting can cause fruit bats to abandon, or temporarily desert, their roosts (Mackinnon et al. 2003) and can therefore have direct and indirect impacts on the bats through mortality and the costs of roost switching respectively. The small fruit bat Rousettus madagascariensis is particularly vulnerable to hunters because it roosts inside caves, or at cave entrances, where hunters can kill or intercept a large number of bats in a short time (e.g., Rakotonandrasana and Goodman 2007). Although $R$. madagascariensis is widespread in eastern and western Madagascar only a few roost sites are known to biologists (Goodman et al. 2005, Cardiff et al. 2009), which suggests that these bats have specific roosting requirements and 


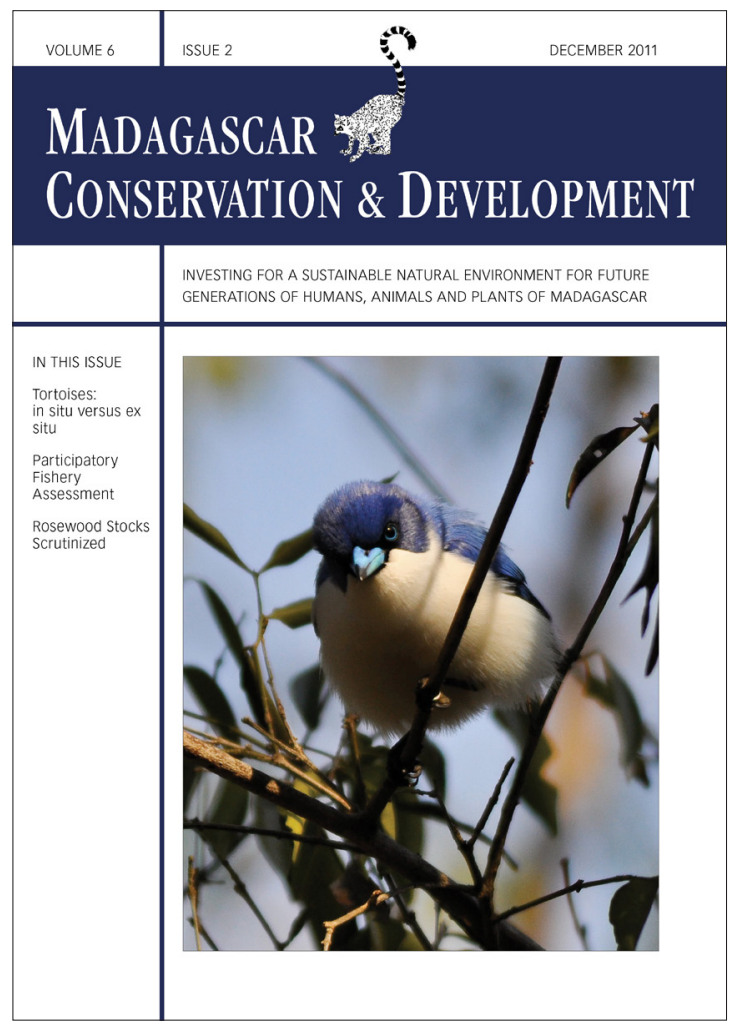

Madagascar Conservation \& Development is the journal of Indian Ocean e-Ink. It is produced under the responsibility of this institution. The views expressed in contributions to MCD are solely those of the authors and not those of the journal editors or the publisher.

All the Issues and articles are freely available at http://www.journalmcd.com

Contact Journal MCD

info@journalmcd.net for general inquiries regarding MCD funding@journalmcd.net to support the journal

Madagascar Conservation \& Development Institute and Museum of Anthropology University of Zurich

Winterthurerstrasse 190

CH-8057 Zurich, Switzerland

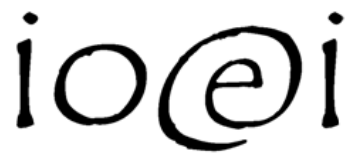

Indian Ocean e-Ink

Promoting African Publishing and Education www.ioeink.com

Missouri Botanical Garden (MBG)

Missouri Botanical Garden

Madagascar Research and Conservation Program BP 3391

Antananarivo, 101, Madagascar 
that suitable caves may be scarce (Cardiff 2006) or that a large number of roosts remain undiscovered.

Unfortunately, even Rousettus madagascariensis colonies in caves inside protected parks and reserves are also subject to illegal hunting (Cardiff et al. 2009). R. madagascariensis roosts are subject to least hunting pressure when the caves are difficult or dangerous for hunters to access or when they are associated with a taboo (fady). Fruit bats are important seed dispersers and pollinators and their conservation therefore maintains ecosystem services (e.g., Hodgkison 2003). Although there are no quantitative studies from Madagascar on the value of these bats to promoting forest regeneration or maintaining the survival of plants of cultural and economic importance, there is evidence that they disperse seeds (Andrianaivoarivelo et al. 2011, Andrianaivoarivelo et al. In press). There are therefore compelling reasons for managing hunting at sustainable levels in some roosts and prohibiting it all together in others.

In this article we present the results from roost surveys conducted between 2006 and 2010 in eastern Madagascar. Conservation work conducted from 2007 in communities living near the roosts focused on raising peoples' awareness about the ecological roles that bats play. In 2008, two of the roosts became focal sites for the creation of new community-managed protected areas where local people were dedicated to conserving and sustainably using the remaining forest and its resources. Both sites, Sahavoa (1,500 ha) and Ambatofotsy (1,200 ha) obtained provisional protected area status in 2008 and although sustainable use is permitted throughout most of the forest, the community groups (Tahiry, Tsinjo, Fanilo and Maintso) have opted to prohibit hunting in the caves. We sought to determine patterns of occupancy in six Rousettus madagascariensis roosts and to evaluate the threats to each site.

\section{METHODS}

This study was conducted in the Anosibe An'Ala District (E047 $57^{\prime}-048^{\circ} 19^{\prime}, \mathrm{S} 19^{\circ} 24^{\prime}-19^{\circ} 32^{\prime}$ ) of the Alaotra Mangoro Region. The western part of the district has retained significant midaltitude humid forest cover but large areas of land are used for agriculture, and slash and burn clearance occurs at the edge of the humid forest.

We used informal discussions with local authorities and the public to discover the whereabouts of Rousettus madagascariensis roosts. Basic information was collected at each roost: entrance height and cave length were measured, and vegetation clutter (branches and leaves) within $10 \mathrm{~m}$ of the main bat emergence exit was classed as high, medium or low. Penetration of caves by people is impeded, or even prevented, by dangerous or blocked access routes. We therefore assessed each cave as providing high, medium or low ease of penetration to people, with features such as steep cliffs, slippery rocks and dense vegetation limiting access during the study. Bat abundance was either assessed by directly counting the number of roosting individuals by torch light, or if the colony size was large, a sample of the roosting bats was counted and extrapolated to the total abundance based on the surface area occupied by the bats (following Albayrak et al. 2008). If a cave was reported by local people as abandoned by bats, and no evidence of bat use was detected during the visits, we obtained information on the last date when people remembered bats being present in the cave. Direct evidence of hunting in each roost was based mainly on the presence of throwing-sticks, traditional blowpipe darts and fires. Slash and burn clearance near the roosts was also noted. We moved throwing-sticks to the side of each cave and checked for new sticks on subsequent visits. Additional information about the roost was obtained during informal interviews with people who lived nearby.

\section{RESULTS}

We found six Rousettus madagascariensis roosts. Four were located in a large block of humid forest, one in the east and three in the west of the Mangoro River and two were in isolated forest fragments, one in the south near Maromitety and one in the northeast near Tsaravinany (Figure 1).

CAVE CHARACTERISTICS. The height of the primary cave aperture at each roost ranged from $2.5 \mathrm{~m}$ to $4.5 \mathrm{~m}$ and the length was between $8 \mathrm{~m}$ and $15 \mathrm{~m}$ (Table 1). Five of the six roosts were located inside humid forest, within $800 \mathrm{~m}$ of the edge, and local people also reported that the Valanirana roost used to be inside the forest but it was cleared of vegetation by farmers prior to 1998. Access to the cave roosts by people was generally difficult, apart from at Valanirana from where all vegetation had been removed. At Androrangabe, the forest adjacent to the roost was replaced by agriculture between our January and December visits in 2008.

BAT COLONIES. Colony size was largest at Antsahahety, followed by Ambohimanjaka with bats often numbering in excess of 500 individuals (Table 1). Colonies at Ambatofotsy and Sahavoa were smaller, with up to a few hundred bats (Table 1). Colony size varied markedly between visits to all caves. At Antsahahety for example, we estimated 4,200 bats in July 2007 but there were only 200 present in December 2008. Whilst at Ambatofotsy, we counted 750 bats in July 2007 and only 40 in December 2008. The colony at Sahavoa underwent a major change in size from 600 bats in November 2009 to a single bat in November 2010.

THREATS. The removal of humid forest around caves

represented a disturbance at three roosts. Local people attributed this to the loss of the bat colony at Valanirana before 2006. Similarly, bats ceased using the cave at Androrangabe after the surrounding forest was cleared in 2007. Slash and burn

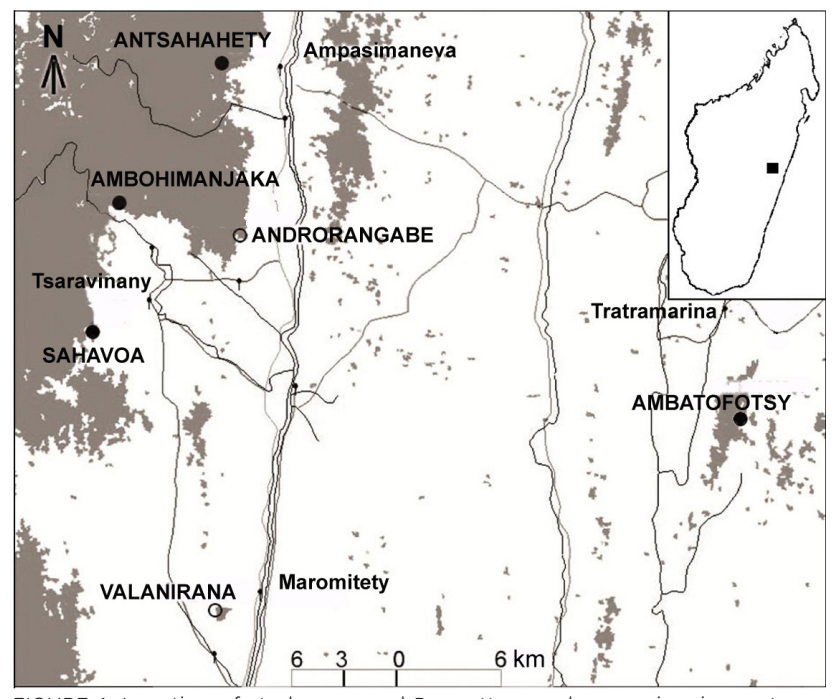

FIGURE 1. Location of study area and Rousettus madagascariensis roosts. $(\bullet=$ occupied roost, $\mathrm{o}=$ abandoned roost, shaded areas = remaining humid forest) 
TABLE 1. The colony size and cave dimensions for six Rousettus madagascariensis roosts. (Valanirana cave was told by local villagers to shelter $R$. madagascariensis before $1998,(\mathrm{dc})=$ direct counts, $(\mathrm{e})=$ estimates, ' $-'$ ' indicates no visit)

\begin{tabular}{|c|c|c|c|c|c|c|}
\hline Month/Year & Ambohimanjaka & Sahavoa & Valanirana & Ambatofotsy & Antsahahety & Androrangabe \\
\hline May 2006 & $800(e)$ & $350(\mathrm{e})$ & - & - & - & $110(\mathrm{dc})$ \\
\hline January 2007 & $600(e)$ & $350(\mathrm{e})$ & - & - & - & $83(\mathrm{dc})$ \\
\hline April 2007 & - & - & - & - & - & - \\
\hline July 2007 & $850(e)$ & $400(e)$ & - & $750(e)$ & $4200(e)$ & - \\
\hline December 2007 & - & - & - & - & - & - \\
\hline December 2008 & $350(e)$ & $250(\mathrm{e})$ & - & $40(\mathrm{dc})$ & $200(e)$ & - \\
\hline March 2009 & $280(e)$ & $400(e)$ & - & $50(\mathrm{dc})$ & $2800(e)$ & - \\
\hline July 2009 & $700(e)$ & $200(e)$ & - & $35(\mathrm{dc})$ & $2000(e)$ & - \\
\hline November 2009 & - & $600(e)$ & - & $70(\mathrm{dc})$ & $800(e)$ & - \\
\hline February 2010 & - & $350(e)$ & - & $110(e)$ & $800(e)$ & - \\
\hline July 2010 & - & $350(\mathrm{e})$ & - & $230(e)$ & $3600(e)$ & - \\
\hline November 2010 & - & 1 & - & $480(\mathrm{e})$ & $1200(e)$ & - \\
\hline Entrance height (m) & 3 & 4 & 3.5 & 2.5 & 4.5 & 4 \\
\hline Maximum cave interior length (m) & 15 & 11 & 9 & 8 & 8 & 11 \\
\hline Roost to interior forest edge (m) & 600 & 200 & No forest & 200 & 800 & 400 \\
\hline
\end{tabular}

occurred within $400 \mathrm{~m}$ of roost entrance at Sahavoa between July and November 2010, and this may have directly impacted the bats, or indirectly impacted them through improved access to the cave for hunters. We found evidence of hunting in all of the five caves used by Rousettus madagascariensis during the study (Supplementary Material S1). This usually consisted of discarded throwing-sticks found inside the cave but also included traditional blow-pipe darts at Sahavoa in November 2010. In December 2008 we encountered evidence of recent hunting at Antsahahety, with four dead and four wounded bats indicating that hunters had been present within hours of our arrival. There were no bats roosting in the cave but a small group of 20 individuals (not included in Table 1) was located on nearby trees and had been discovered by a diurnal raptor (Buteo brachypterus). The day after, approximately 200 bats returned to the cave (Table 1). Hunting at the Ambatofotsy roost appeared to have declined since 2008 and there was a gradual increase in bats between 2008 and 2010. The local people and authorities with whom we spoke informally during the course of our work were unaware of the number of active bat hunters and generally appeared reticent to inform us about hunting. We did not find any evidence of fruit bats in the markets or restaurants in three towns in the study area (Ampasimaneva, Maromitety and Tsaravinany). We therefore tentatively conclude that hunting is undertaken by a small number of individuals at each roost, and that bats are destined for domestic consumption. The blow darts we observed in the Sahavoa cave resembled those used by lemur hunting in the Anosibe An'Ala District and the bats may have been targeted during general hunting missions.

\section{DISCUSSION}

This survey found four active cave roosts of Rousettus madagascariensis in humid forests that are currently threatened through deforestation and hunting. There was considerable variation in the size of the bat colonies in the different caves, and between different visits to the same cave. This variation was probably caused by anthropogenic disturbance and the mobile habits of this species.
METHODOLOGICAL CAVEATS. Cavernicolous bats that roost in colonies are difficult to count (e.g., Cardiff et al. 2009). Although we reduced potential observer bias through largely maintaining the same survey team it was still difficult to count the bats because some individuals may have remained hidden from view. Also, we were unable to maintain a systematic survey schedule and certain sites received more visits over a longer duration than others. Even though the evidence of a gap in information caused by the lack of confidence from villagers, we did not see the hunters as well but the results of our interview and observation would be sufficient to argue the fact that, Rousettus madagascariensis is threatened in its day roost. Within this context, it is particularly important to revisit Sahavoa, Ambohimanjaka and Androrangabe in the future to determine if the bats have resumed use of these caves.

COLONY SIZE. Colony size in the roosts that we visited were generally less than a thousand individuals and therefore smaller than those reported from Ankarana Special Reserve and Mahavavy-Kinkony (Rakotoarivelo and Randriandrianina 2007, Cardiff et al. 2009) in the north and west of Madagascar, respectively. However, colonies of Rousettus madagascariensis elsewhere, such as in the Anjohikinakina cave at Tsingy de Bemaraha National Park in the center west of Madagascar and Ankerana cave on Île Sainte Marie in the east, were smaller in size and more similar to those in this study (Kofoky et al. 2007, Rakotonandrasana and Goodman 2007).

ROOSTING ECOLOGY. In areas with a high abundance

of caves, Rousettus madagascariensis occupancy rates are rather low, suggesting that this species has rather narrow requirements for roosting conditions (Kofoky et al. 2007, Cardiff et al. 2009). All of the roosts in our study were currently, or formerly, found inside humid forest and it is possible that vegetation reduces predation pressure from birds or helps to maintain the microclimate in the caves (Fenton 1983, Jenkins et al. 1998). The extent to which forest cover influences the suitability of caves will likely depend on particular cave characteristics at each site, and further research is needed to better understand the roosting biology of $R$. madagascariensis. Goodman et al. (2005) noted that a R. madagascariensis roost 
in Anjohibe in western Madagascar was at least $30 \mathrm{~km}$ from the nearest degraded forest and concluded that this was not a forest-dependent species. The extent to which this species requires forest, either when related to roosting conditions or food supply is poorly understood. In the east of Madagascar, for example, it feeds on forest trees as well as plants located in gardens and plantations (Andrianaivoarivelo et al. 2011).

The variation in colony size in our study could have been the result of bats temporarily deserting the cave during hunting, normal dispersal or observer error. The latter may explain relatively small differences between surveys but we occasionally encountered very large differences in abundance that could only be caused by the presence of fewer bats in the cave compared to previous visits. Madagascar has a single Rousettus madagascariensis population with relatively frequent mixing of individuals and weak genetic differentiation (Goodman et al. 2010). R. madagascariensis regularly travel over $8 \mathrm{~km}$ at night (Andrianaivoarivelo et al. 2011) and the roosts in our survey may be acting as a meta-roost with regular exchange of bats. The bats therefore probably move frequently and over considerable distances, although there is little information however on triggers for roost-switching, and especially the role that hunting and the spatial variation in food resources play. Our observations at Antsahahety and Sahavoa show that $R$. madagascariensis react to hunting by deserting the roosts. At Antsahahety and Ambatofotsy at least, the bats had returned by our subsequent visits some months later, but our data set does not provide information on the pace or timing of the recovery. It is important to track the future of the Sahavoa colony since the colony had declined to a single bat in November 2010. It is premature however to attribute causality to a particular type of disturbance until more is known about the roosting ecology of these bats in sites where they are not hunted. Additional information is required on $R$. madagascariensis movements between roosts, both at the scale of our study and at the regional or national level within Madagascar.

CONSERVATION. Successful conservation of the Rousettus madagascariensis initially requires effective measures targeted at the proximate threats to the sites. Our results indicate that hunting for bushmeat is a direct threat inside caves and that although this initially reduces the number of bats and causes roost desertion, the bats are able to return to the roost. Our results also suggest that the removal of humid forest around the caves is an indirect threat because it renders the roost sites less suitable for $R$. madagascariensis. Whilst the reduction of hunting might be favourable from a conservation stand point, $R$. madagascariensis is a game species (Category III, Décret 2006400) and can be legally hunted between 1 May and 1 September (Rakotoarivelo et al. 2011). This legislation is difficult to enforce because of the difficulty of the access to the sites (at least one day following foot paths from the nearest village) absence of means and conservation agency in the areas (office and personnel), and people hunt $R$. madagascariensis outside the legal season in our study sites and elsewhere in Madagascar (Rakotonandrasana and Goodman 2007, Jenkins and Racey 2008, Golden 2009). Data on the demand for $R$. madagascariensis meat is lacking although it seems that fruit bats are not a widely appreciated bushmeat in eastern Madagascar (Jenkins et al. 2011). The decisions whether to allow hunting at roosts during the four-month open season, or to establish local conventions to prohibit hunting are made by local communities who have management rights of the forest. In Anosibe An'Ala the consensus during consultations with community groups and local authorities at Sahavoa and Ambatofotsy was for sustainable management of the forests whilst prohibiting hunting within the $R$. madagascariensis roost all year around. Conservation activities at these sites therefore now have a strong mandate and both are included in the list of new protected areas in Madagascar. Hunting and deforestation continue to threaten these forests and additional effort is now needed to deliver effective community conservation.

\section{ACKNOWLEDGMENTS}

We thank the Ministry of Environment, Forests and Tourism in Madagascar for granting permission for this study, which was funded by the Disney Worldwide Conservation Fund (2006 and 2008) a Rufford Small Grant to R. A. Andrianaivoarivelo (2008), National Geographic Society Conservation Trust and the Darwin Initiative. Idea Wild provided essential fieldwork equipment to CR and SR. We are also grateful to D. Rakotondravony for academically supporting this project. We are also extremely grateful to M. Rakotoarinosy, Chef de District of Anosibe An'Ala and the mayors of Anosibe An'Ala, Niarovana, Tsaravinany, Ampasimaneva and Tratramarina districts for their assistance. Three reviewers are acknowledged for their helpful comments.

\section{REFERENCES}

Albayrak, I., A an, N. and Yorulmaz, T. 2008. The natural history of the Egyptian fruit bat, Rousettus aegyptiacus, in Turkey (Mammalia: Chiroptera). Turkish Journal of Zoology 32: 11-18.

Andriafidison, D., Cardiff, S. G., Goodman, S. M., Hutson, A. M., Jenkins, R. K. B., Kofoky, A. F., Rabearivelo, A., Racey, P.A., Ranivo, J., Ratrimomanarivo, F. H. and Razafimanahaka, H. J. 2008a. Pteropus rufus. In: IUCN Red List of Threatened Species Version 2011.1. <wwW. iucnredlist.org> accessed 24 October 2011.

Andriafidison, D., Cardiff, S. G., Goodman, S. M., Hutson, A. M., Jenkins, R. K. B., Kofoky, A. F., Racey, P.A., Ranivo, J., Ratrimomanarivo, F.H. and Razafimanahaka, H. J. 2008b. Eidolon dupreanum. In: IUCN 2011. IUCN Red List of Threatened Species. Version 2011.1. <www.iucnredlist. org > accessed 24 October 2011.

Andriafidison, D., Cardiff, S. G., Goodman, S. M., Hutson, A. M., Jenkins, R. K. B., Kofoky, A. F., Racey, P. A., Ranivo, J., Ratrimomanarivo, F. H. and Razafimanahaka, H. J. 2008c. Rousettus madagascariensis. In: IUCN Red List of Threatened Species. Version 2011.1. <www.iucnredlist. org > accessed 24 October 2011.

Andrianaivoarivelo, R. A., Petit E. J., Razafindrakoto, N. and Racey P. A. 2012 (In press). Alimentation et dispersion de graines chez Rousettus madagascariensis G. Grandidier 1928, dans le Nord-Ouest de Madagascar. Revue d'Écologie (Terre et Vie) 67

Andrianaivoarivelo, R. A., Ramilijaona, O. R. and Andriafidison, D. 2007. Rousettus madagascariensis Grandidier 1929 feeding on Dimnocarpus longan in Madagascar. African Bat Conservation News 11: $3-4$.

Andrianaivoarivelo, R. A., Ramilijaona, O. R., Racey, P. A., Razafindrakoto, N. and Jenkins, R. K. B. 2011. Feeding ecology, habitat use and reproduction of Rousettus madagascariensis Grandidier, 1928 (Chiroptera: Pteropodidae) in eastern Madagascar. Mammalia 75, 1: 69-78. (doi:10.1515/MAMM.2010.071)

Cardiff, S. G. 2006. Bat Cave Selection and Conservation in Ankarana, Northern Madagascar. Unpub. MSc. Thesis, Columbia University, New York.

Cardiff, S. G., Ratrimomanarivo, F. H., Rembert, G. and Goodman, S. M. 2009. Hunting, disturbance and roost persistence of bats in caves at Ankarana, northern Madagascar. African Journal of Ecology 47, 4: 640-649. (doi:10.1111/j.1365-2028.2008.01015.x)

Durbin, J. 2007. New legislation for the protection of Malagasy species. Lemur News 11: 4-6. 
Fenton, M. B. 1983. Roosts used by the African bat, Scotophilus leucogaster (Chiroptera: Vespertilionidae). Biotropica 15, 2: 129-132.

Golden, C. D. 2009. Bushmeat hunting and use in the Makira Forest, northeastern Madagascar: A conservation and livelihoods issue. Oryx 43, 3: 386-392. (doi:10.1017/S0030605309000131)

Goodman, S. M., Andriafidison, D. Andrianaivoarivelo, R., Cardiff, S. G. Ifticene et al. 2005. The distribution and conservation of bats in the dry regions of Madagascar. Animal Conservation 8: 153-165. (doi:10.1017/ S136794300500199X)

Goodman, S. M., Chan, L. M., Nowak, M. D. and Yoder, A. D. 2010. Phylogeny and biogeography of western Indian Ocean Rousettus (Chiroptera: Pteropodidae). Journal of Mammalogy 91, 3: 593-606. (doi:10.1644/09MAMM-A-283.1)

Hodgkison R., Balding S. T., Zubaid A., and Kunz T. H. 2003. Fruit bats (Chiroptera: Pteropodidae) as seed dispersers and pollinators in a lowland Malaysian rain forest. Biotropica 35, 4: 491-502. (doi:10.1646/03043)

Jenkins, E. V., Laine, T., Morgan, S. E., Cole, K. R. and Speakman J. R. 1998. Roost selection in the pipistrelle bat, Pipistrellus pipistrellus (Chiroptera: Vespertilionidae), in northeast Scotland. Animal Behaviour 56, 4: 909-917. (doi:10.1006/anbe.1998.0858)

Jenkins, R. K. B. and Racey, P. A. 2008. Bats as bushmeat in Madagascar. Madagascar Conservation \& Development 3, 1: 22-30.

Jenkins, R. K. B., Keane, A., Rakotoarivelo, A. A., Rakotomboavonjy, V., Randrianandrianina, F. H., Razafimanahaka, H. J., Ralaiarimalala, S. R. and Jones, J. P. G. 2011. Analysis of patterns of bushmeat consumption reveals extensive exploitation of protected species in eastern Madagascar. PLOS ONE 6, 12: e27570. (doi:10.1371/journal. pone.0027570)

Kofoky A., Andriafidison D., Ratrimomanarivo F., Razafimanahaka H. J., Rakotondravony D., Racey P. A. and Jenkins R. K. B. 2007 . Habita use, roost selection and conservation of bats in Tsingy de Bemaraha National Park, Madagascar. Biodiversity \& Conservation 16, 4: 1039-1053. (doi:10.1007/s10531-006-9059-0)

Mackinnon, J. L., Hawkins, C. E. and Racey, P. A. 2003. Pteropodidae, fruit bats. In: The Natural History of Madagascar. S. M. Goodman and J. P. Benstead (eds.), pp 1299-1302. The University of Chicago Press, Chicago.

Racey, P. A., Goodman, S. M. and Jenkins, R. K. B. 2010. The ecology and conservation of Malagasy bats. In: Islands Bats: Evolution, Ecology, and Conservation. T. H. Fleming and P. A. Racey (eds.), pp 369-404. The University of Chicago Press, Chicago.

Rakotoarivelo, A. R. and Randrianandrianina, F. H. 2007. A Chiropteran survey of the Lac Kinkony-Mahavavy area in western Madagascar. African Bat Conservation News 12: 2-5.

Rakotoarivelo, A. R., Razafimanahaka, H. J., Rabesihanaka, S., Jones, J. P. G. \& Jenkins, R. K. B. 2011. Lois et règlements sur la faune sauvage à Madagascar: Progrès accomplis et besoins du futur. Madagascar Conservation \& Development 6, 1: 37-44

Rakotonandrasana, E. N. and Goodman, S. M. 2007. Bat inventories of the Madagascar offshore islands of Nosy Be, Nosy Komba and Ile SainteMarie. African Bat Conservation News 12: 6-10.

\section{SUPPLEMENTARY MATERIAL. AVAILABLE ONLINE ONLY.}

TABLE S1: Summary of hunting evidence, habitats and conservation action at six Rousettus madagascariensis roosts from 2006 to 2010. 